\title{
The Evaluation of Yield and Agronomic Traits of Flax Genotypes Under Latvian Conditions
}

\author{
Inga Stafecka \\ Institute of Agricultural Resources and \\ Economics \\ Vilani, Latvia \\ email: inga.stafecka@arei.lv \\ Aldis Starmkalis \\ Institute of Agricultural Resources and \\ Economics \\ Vilani, Latvia
}

\author{
Veneranda Stramkale \\ Institute of Agricultural Resources and \\ Economics \\ Vilani, Latvia \\ veneranda.stramkale@arei.lv
}

\author{
Ieva Kroiča \\ Institute of Agricultural Resources and \\ Economics \\ Vilani, Latvia
}

\begin{abstract}
This study aim was evaluated of flax genotypes regarding productivity, resistance to lodging and diseases as well as yield dependence relationships among phenotypic and quality traits. The 14 fibre flax genotypes were evaluated in field conditions on the background of natural infection from 2014 to 2018 for agronomically important traits and from 2015 to 2018 for occurrence diseases of flax. The data were recorded for the $\mathbf{1 5}$ following agronomic traits, such days to flowering, days to early yellow ripening stage, total plant height, technical height, stem yield, fibre content, 1000 seed weight, vessels per plant, harvest index, seed yield, oil content, resistance to lodging and fungal diseases during early yellow ripening stage. Genotypic and phenotypic correlations between yield and yield components were identified that total plant height, technical height and days to early yellow ripening stage played a major role on stem yield as well vessels per plant and harvest index on seed yield. The flax genotypes 'Vilani', 'L26-1', 'K9-1', 'T361', 'S37-1' exhibited significant highest stem yield ranging from 643.20 to $693.32 \mathrm{~g} \mathrm{~m}^{-2}$ and technical length ranging from 65.90 to $70.58 \mathrm{~cm}$ comparing to standard variety 'Vega 2'. The most perspective genotype of 'Vilani' with quit low susceptibility to anthracnose, pasmo and powdery mildew and resistance to lodging was identified.
\end{abstract}

Key words-agronomic traits, correlations coefficient, diseases, fibre flax, yield

\section{INTRODUCTION}

Flax a multipurpose crop cultivated for fibre and seeds. Many investigators indicated that flax genotypes significantly differed in their growth habits and their response to cultural practices as well as production of fibre and oil, of them [1] - [4].

Similar like in the Latvia, in the Europe the aims of new flax varieties are: resistance to lodging reaching 9 points of the grade, middle early vegetation period, yield potential of stem reaching $7-8 \mathrm{tha}^{-1}$, yielding potential of the seeds reaching $1.10-1.30 \mathrm{t} \mathrm{ha}^{-1}$ in the trials [5]. Yield is the most important and complex trait in crops that show correlations with other traits [6]. Being a polygenic trait it is greatly influenced by environmental fluctuations. To obtain superior varieties with high yielding potential, the plant breeder has to deal with characters, which are governed by polygenic systems and show continuous variation [7]. Other important agronomic traits such as flowering time, plant height, plant branching, and lodging resistance may also indirectly affect yield through various physiological mechanisms [6], [8], allowing crop phenology and plant architecture to be adapted to regional growing conditions, thus avoiding yield and quality losses [9]. Knowledge of association between yield and its attributes obtainable through estimation of genotypic and phenotypic correlation helps to formulate plant breeding strategies to develop suitable genotypes [10], [11]. The positive correlation between major yield components, breeding strategies would be very effective but on the reverse, selection becomes very difficult [12].

Flax yield and profitability can be greatly affected by diseases occurrences. Pasmo, anthracnose, powdery mildew are fungal diseases of flax and attacking all aboveground parts of the plant. These diseases can reduce the yield and quality of seed and fiber raw materials, with most losses resulting from premature ripening and loss of seed during harvest, although reductions in seed number per plant can occur with early infection [13] - [15].

In recent years, it has become more difficult to breed new fibre flax varieties with a better fibre quality, increased fibre yield, and the required resistance, due to repeated use of modern cultivars as crossing parents [5]. Therefore, the aim of this study was evaluated of flax genotypes regarding productivity, resistance to lodging and diseases as well as yield dependence relationships among phenotypic and quality traits.

\section{MATERIALS AND METHODS}

\section{A. Field Trails}

The research was conducted at the Institute of Agricultural Resources and Economics, Research Centre of Priekuli, research unit Vilani since 2014 to 2018 for agronomically important traits of flax and since 2015 to 2018 for occurrence of fungal diseases during early yel- 
low ripening stage. Experimental material for the study consisted of 13 fibre flax genotypes of the Latvian origin "(Table 1)" and 'Vega 2' (ST) as the standard variety of Lithuanian origin. Since 2017 the variety 'Vilani' (breeding line ('I18-1')) has been tested successfully for DUS and for VCU is still on the way.

TABLE 1

ESTIMATED FIBRE FLAX GENOTYPES

\begin{tabular}{|l|c|l|c|}
\hline Nr. & $\begin{array}{c}\text { Geno- } \\
\text { type }\end{array}$ & Nr. & Genotype \\
\hline 1. & S29-1 & $\mathbf{8 .}$ & K9-1 \\
\hline 2. & S29-2 & $\mathbf{9 .}$ & K9-2 \\
\hline 3. & S37-1 & $\mathbf{1 0 .}$ & L26-1 \\
\hline 4. & S37-2 & $\mathbf{1 1 .}$ & I7-1 \\
\hline 5. & T36-1 & $\mathbf{1 2 .}$ & I7-2 \\
\hline 6. & T36-2 & $\mathbf{1 3 .}$ & Vilani (I18-1) \\
\hline 7. & T36-3 & ST & Vega 2 \\
\hline
\end{tabular}

The experiment was set up in randomized block design in three replicates at $2 \mathrm{~m}^{2}$ with a distance between rows 10 cm. Flax was grown in Humic Gleyic Podzols (PZ-gl-hu) soil [16]. The main agrochemical parameters of the arable soil layer were following: humus content $-6.5 \%$, soil acidity $\left(\mathrm{pH}_{\mathrm{KCl}}\right)-6.4-7.0$, available $\mathrm{P}_{2} \mathrm{O}_{5}-130-145 \mathrm{mg}$ $\mathrm{kg}^{-1}$ and available $\mathrm{K}_{2} \mathrm{O}-118-124 \mathrm{mg} \mathrm{kg}^{-1}$ soil. Complex fertilizer NPK 16:16:16 - $300 \mathrm{~kg} \mathrm{ha}^{-1}$ was applied after first soil cultivation. 1700 flax seeds per $1 \mathrm{~m}^{2}$ were sown by hand with sowing depth $1.5-2 \mathrm{~cm}$ at the field trial. Prior to sowing, germination tests were performed for all used genotypes. Seeds were sown during the first 10 days of May. For plants' further development a surface fertilizer ammonium nitrate $30 \mathrm{~kg} \mathrm{ha}^{-1} \mathrm{~N}$ in fir-tree like phase was applied. Insecticides (Fastac $500.4 \mathrm{~L} \mathrm{ha}^{-1}$, a.s. $50.0 \mathrm{~g} \mathrm{~L}^{-1}$ alpha-cypermethrin) were sprayed against flax flea beetles (Aphthona euphorbiae) as required by the instructions. The tractor-drawn sprayer "Pilmet 412" was used for insecticide application. Fungicides for flax diseases were not used at all. Plants were pulled manually at the stage of early yellow ripeness and then left on ground for airdrying for 5-8 days. The seed-vessels were removed by "Eddi" device. Seeds were cleaned with sample cleaner MLN (Pfeuffer GmbH, Germany). The yield of seeds was weighed and then re-calculated to weight by $100 \%$ purity and $12 \%$ humidity. Seed oil content was determined on grain quality analyzer "Infratec 1241" (FOSS, Denmark). The total and technical plant heights, fibre content were determined using randomly selected most typical 20 plants in each parcel area before the harvest. The yields of stem and seed were determined in each harvested parcel area. The resistance of plants to lodging, length of growth stages of flax were evaluated [17]. The harvest index (HI) was calculated in percentage as the ratio of seed yield to plant weight after plant maturity [10].

Thirty flax plants from each genotype at the $2 \mathrm{~m}^{2}$ in the field trails were assessed during early yellow ripening stage under field conditions with natural infection background. The analyses of infected parts of the plants were done following the methodologies developed for phytopathological research [18]. The diseases were determined by morphological features were using disease descriptors [18], [19]. Percentage of the affected plants was estimated and disease severity was recorded for the whole plant for each disease following a five-point scale: 0 - healthy, 1 - weakly affected, 2 - moderately affected, 3 - heavily affected, 4 - very heavily affected or dead plants. Disease severity index “(1)" was calculated by applying formula [18]:

$$
\mathrm{DSI}=\frac{\sum(\mathrm{ab}) \times 100}{\mathrm{~A} \times \mathrm{S}},
$$

where DSI is disease severity index, $\%$, a - number of infected plants, $\mathrm{b}$ - degree of infection used five-point scale, A - total number of plant samples (healthy and infected), $\mathrm{S}-$ the highest degree of infection.

\section{B. Meteorological Conditions}

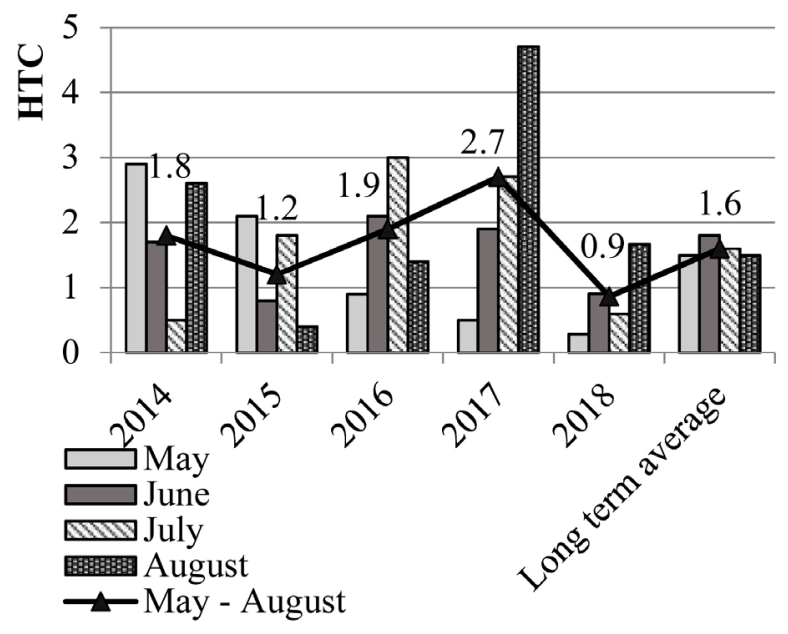

Fig. 1. Hydrothermal coefficients (HTC) during the growth period of flax from 2014 to 2018 .

Agro-meteorological conditions were determined by ADCON installed meteorological stations connected to the computer program Dacom Plant Plus. The facility provides information directly to the nearby field trials. In this study hydrothermal coefficient (HTC) of each month was calculated during the growing season "(Fig. 1.)". The calculations were performed "(2)" by applying formula [20]:

$$
\mathrm{HTC}=\Sigma \mathrm{x} / \Sigma \mathrm{t} \times 10,
$$

where $\Sigma \mathrm{x}$ and $\Sigma \mathrm{t}$-sum of precipitations and temperatures in the period, when the temperature has not been lower than $10^{\circ} \mathrm{C}$.

Ranges of values of this index were classified according to Sielyaninov in the modification of [21] as: $\mathrm{HTC} \leq 0.4$ extremely dry; $0.4<\mathrm{HTC} \leq 0.7$ very dry; 0.7 $<\mathrm{HTC} \leq 1.0$ dry; $1.0<\mathrm{HTC} \leq 1.3$ relatively dry; $1.3<$ HTC $\leq 1.6$ optimal; $1.6<\mathrm{HTC} \leq 2.0$ relatively humid; $2.0<\mathrm{HTC} \leq 2.5$ humid; $2.5<\mathrm{HTC} \leq 3.0$ very humid; HTC $>3.0$ extremely humid.

The hydrothermal conditions during the growing stages of flax differed "(Fig. 1.)". The relatively humid 
was recorded in 2014 and 2016 (1.8 and 1.9, respectively), relatively dry in 2015 (1.2) and dry in 2018 (0.9). The very humid was recorded in 2017, especially extremely higher humidity in August, where was about 317\% higher than the long-term average.

\section{Statistical Analysis}

MS-Excel software was used for data statistical analysis and correlations. Significant differences among the measured characteristics of flax genotypes were compared by Fisher's protected least significant difference (LSD) tests $(\mathrm{p} \leq 0.05)$. Phenotypic and genotypic coefficients of correlation for yield and agronomic traits were identified $[22 ; 23]$.

\section{RESULTS AND DISCUSSION}

All the agronomic traits measures determined for flax were significantly $(p \leq 0.05)$ dependent on genotype "(Table 2)". The significant $(\mathrm{p} \leq 0.05)$ highest total plant height was observed of genotypes 'Vilani', 'K9-1', 'K92 ' and 'L26-1' with the range

from 82.42 to $85.35 \mathrm{~cm}$, the technical plant height of genotypes 'T36-3', 'I7-2', 'T36-1', 'K9-2', 'T36-2', 'Vilani', 'K9-1' and '26-1' with the range from 64.26 to $70.58 \mathrm{~cm}$ and the fibre content of genotypes 'T363', 'T36-2', 'S37-2' and 'T36-1' with the range from 32.58 to $34.88 \%$ compared with the standard 'Vega
2'(ST). A study by [4], [24] has revealed that the plant technical height, fibre percentage and plant type (height, branch number, etc.) are the essential indexes for fibre flax breeding. In this study results was observed variable genetic resources where not all genotypes with highly technical height or stem yield had a great amount of fibre contents. Results have identified the diversity of flax genetic resources with perspective to find out genotypes useful for different purposes.

The significant $(\mathrm{p} \leq 0.05)$ highest stem yield was observed of genotypes 'S37-1', 'T36-1', 'K9-1', 'Vilani', 'L26-2' with the range from 643.12 to $693.32 \mathrm{~g} \mathrm{~m}^{-2}$ and the seed yield of genotypes 'S37-1', 'Vilani', 'S29-2', 'I71 ' with the range from 136.08 to $147.86 \mathrm{~g} \mathrm{~m}^{-2}$ compared with the standard 'Vega 2'(ST). The harvest index (HI) ranged from $15.49 \%$ to $20.87 \%$ between genotypes was identified insignificant different. According to [17] the flax descriptors list all genotypes were identified medium vegetation period where average day's number from seedling to flowering ranged from 57 to 61 days and to early yellow ripening stage from 98 to 104 days.

In this study, the genotypic and phenotypic correlation coefficient was similar in directions, while in magnitude, genotypic correlations were mostly higher than corresponding phenotypic correlations "(Table 3)".

TABLE 2

AgRonOMic tRAITS OF FLAX GENOTYPES

\begin{tabular}{|c|c|c|c|c|c|c|c|c|c|}
\hline Genotype & ToH, cm & TH, cm & StY, $\mathrm{g} \mathrm{m}^{-2}$ & FC, \% & SY, $\mathbf{g ~ m}^{-2}$ & OC, $\%$ & HI, \% & DF & VP \\
\hline S29-1 & 74.80 & 59.82 & 538.12 & 29.58 & 123.76 & 42.65 & 19.19 & 60 & 99 \\
\hline S29-2 & 74.60 & 60.30 & 630.46 & 29.28 & 145.20 & 43.13 & 19.13 & 61 & 101 \\
\hline S37-1 & 75.72 & 60.92 & 555.32 & 34.02 & 136.08 & 43.00 & 20.58 & 60 & 102 \\
\hline S37-2 & 76.86 & 62.74 & 643.12 & 29.72 & 133.88 & 42.28 & 17.64 & 60 & 102 \\
\hline T36-1 & 79.46 & 65.90 & 643.20 & 34.88 & 107.04 & 44.70 & 15.49 & 58 & 99 \\
\hline T36-2 & 80.78 & 67.88 & 600.52 & 33.68 & 114.96 & 43.85 & 17.27 & 58 & 98 \\
\hline T36-3 & 77.62 & 64.26 & 552.96 & 32.58 & 135.50 & 44.85 & 20.57 & 57 & 99 \\
\hline K9-1 & 83.36 & 69.00 & 649.06 & 28.00 & 121.68 & 43.50 & 17.15 & 61 & 103 \\
\hline K9-2 & 83.28 & 67.88 & 610.72 & 26.04 & 127.22 & 43.33 & 18.92 & 61 & 103 \\
\hline L26-1 & 85.12 & 70.58 & 693.32 & 29.26 & 125.48 & 43.23 & 16.58 & 63 & 104 \\
\hline I7-1 & 78.04 & 63.06 & 598.32 & 26.60 & 147.86 & 41.50 & 20.87 & 58 & 100 \\
\hline I7-2 & 80.54 & 65.86 & 617.12 & 27.48 & 133.36 & 42.73 & 18.40 & 58 & 101 \\
\hline Vilani & 82.42 & 67.96 & 668.80 & 29.02 & 141.06 & 42.43 & 18.68 & 58 & 98 \\
\hline Vega 2 & 72.98 & 58.32 & 556.80 & 26.38 & 115.28 & 42.68 & 18.18 & 59 & 101 \\
\hline $\operatorname{LSD}_{0.05}$ & 8.67 & 5.86 & 86.19 & 3.98 & 22.06 & 0.92 & & & \\
\hline
\end{tabular}

ToH- total plant height, TH - technical height, StY - stem yield, FC - fibre content, SY - seed yield, OC - oil content, HI - harvest index, DF - days to flowering, VP - days to early yellow ripening stage; LSD values significant at $\mathrm{p} \leq 0.05$ are marked in bold comparing with 'Vega 2' (ST) 


\begin{tabular}{|c|c|c|c|c|c|c|c|c|c|c|c|}
\hline ТоН & TH & StY & FC & SY & HI & VpP & SW & $\mathrm{OC}$ & DF & VP & \\
\hline ToH & - & $0.98 * *$ & $0.70 * *$ & -0.10 & -0.13 & $-0.55^{*}$ & 0.09 & 0.7 & 0.19 & 0.29 & 0.22 \\
\hline ГН & $0.93 * *$ & - & $0.70^{* *}$ & 0.03 & -0.19 & $-0.59 *$ & -0.05 & 0.26 & 0.30 & 0.20 & 0.14 \\
\hline StY & $0.62^{*}$ & $0.57^{*}$ & - & -0.12 & 0.02 & $-0.63^{*}$ & 0.13 & -0.29 & -0.03 & 0.39 & 0.29 \\
\hline FC & -0.28 & -0.17 & -0.09 & - & -0.30 & -0.14 & $-0.65 *$ & 0.36 & $0.64 *$ & -0.30 & -0.37 \\
\hline SY & -0.23 & -0.06 & 0.00 & 0.17 & - & $0.76^{* *}$ & $0.75^{* *}$ & -0.19 & $-0.53^{*}$ & 0.02 & 0.05 \\
\hline HI & $-0.54^{*}$ & $-0.54^{*}$ & $-0.80^{* *}$ & 0.11 & $0.56^{*}$ & - & 0.49 & 0.04 & -0.37 & -0.22 & -0.13 \\
\hline VpP & 0.40 & 0.19 & 0.22 & -0.51 & -0.12 & & - & -0.36 & $-0.72 * *$ & 0.29 & 0.35 \\
\hline SW & -0.21 & -0.10 & -0.11 & 0.11 & 0.07 & 0.10 & -0.20 & - & $0.53 *$ & $-0.76^{* * *}$ & -0.58 * \\
\hline OC & 0.17 & 0.26 & 0.09 & 0.34 & -0.23 & -0.18 & -0.40 & 0.23 & - & -0.17 & -0.11 \\
\hline DF & 0.23 & 0.02 & 0.05 & 0.05 & $-0.53^{*}$ & -0.38 & 0.28 & -0.26 & -0.01 & - & $0.80 *$ \\
\hline VP & 0.36 & 0.21 & $0.59 *$ & 0.18 & -0.18 & $-0.64 *$ & 0.17 & -0.27 & 0.06 & $0.63 *$ & - \\
\hline
\end{tabular}

Genotypic correlation coefficient are marked in bold; ToH- total plant height, TH - technical height, StY - stem yield, FC - fibre content, SY - seed yield, HI - harvest index, VpP - vessels per plant, SW - 1000 seed weight, OC - oil content, DF - days to flowering, VP - days to early yellow ripening stage; * - correlation significant at $\mathrm{p} \leq 0.05 ; * *-$ at $\mathrm{p} \leq 0.01$

The similar results [7], [10], [25] were obtained that genotypic correlation coefficients were higher than their respective phenotypic correlation coefficients for most of the characters. A study by [26], [27] has revealed that genotypic correlations are higher because of environment had a small role in the expression of the traits, which suggests an inherent association between these traits at the genetic level. In the present study, stem yield showed a positive significant genotypic and phenotypic relationships with total plant height $\left(\mathrm{r}_{\mathrm{g}}=0.70^{* *} ; \mathrm{r}_{\mathrm{ph}}=0.62 *\right)$ technical height $\left(\mathrm{r}_{\mathrm{g}}=0.70^{* *} ; \mathrm{r}_{\mathrm{ph}}=0.57^{*}\right)$ and phenotypic relationship with days to early yellow ripening stage $\left(\mathrm{r}_{\mathrm{ph}}=0.59^{*}\right)$. This fact suggests that flax accessions consist genotypes were showed the productivity of stem yield when are the highest plant heights and length of vegetation period. However, in this study stem yield and days to early yellow ripening stage have only phenotypic correlation where open the possibility find out for breeding of early highly productive genotypes. [28], [29] also drew similar conclusions under low correlation between these characters. The negative significant at genotypic and phenotypic level showed relationships harvest index with stem yield $\left(\mathrm{r}_{\mathrm{g}}=-0.63 * ; \mathrm{r}_{\mathrm{ph}}=-0.80^{* *}\right)$, total plant height $\left(\mathrm{r}_{\mathrm{g}}=-0.55^{*} ; \mathrm{r}_{\mathrm{ph}}=-0.54 *\right)$, technical height $\left(\mathrm{r}_{\mathrm{g}}=-0.59 * ; \mathrm{r}_{\mathrm{ph}}=\right.$ $-0.54 *)$.

The positive significant genotypic and phenotypic relationship showed between seed yield and harvest index $\left(\mathrm{r}_{\mathrm{g}}=0.76^{* *} ; \mathrm{r}_{\mathrm{ph}}=0.56^{*}\right)$ and at phenotypic level with vessels per plant $\left(\mathrm{r}_{\mathrm{g}}=0.75^{* *} ; \mathrm{r}_{\mathrm{ph}}=0.56^{*}\right)$ as well significant negative at genotypic level with oil content $\left(\mathrm{r}=-0.53^{*}\right)$. Similar results a findings about seed yield at phenotypic level and at both levels have been reported by [7], [30] - [34]. This analysis was indicated that for fibre flax the highest seed yield when the highest harvest index and vessels per plant.

The inter correlation between yield components characters may affect the plant breeding for component traits either in favourable or unfavourable direction. The positive significant genotypic and phenotypic relationship showed between technical height and total plant height $\left(\mathrm{r}_{\mathrm{g}}=0.98^{* *} ; \mathrm{r}_{\mathrm{ph}}=93^{* *}\right)$. The oil content showed a positive significant only at genotypic level relationships with fibre content $\left(\mathrm{r}_{\mathrm{g}}=0.64^{*}\right), 1000$ seed weight $\left(\mathrm{r}_{\mathrm{g}}=0.53^{*}\right)$ and significant negative with vessels per plant $\left(\mathrm{r}_{\mathrm{g}}=-0.72 * *\right)$. The 1000 seed weight showed a negative significant at genotypic level with days to flowering and days to early yellow ripening stage $\left(\mathrm{r}_{\mathrm{g}}=-0.76^{* *} ; \mathrm{r}_{\mathrm{g}}=-0.58^{*}\right)$.

The flax yield formation of the majority of characters depends not on one factor, but on factors system and interaction between abiotic and biotic stresses. The new flax varieties should be resistant to lodging and diseases [35]. In this study the powdery mildew, anthracnose and pasmo severity index variable between the genotypes from 2015 to 2018. The powdery mildew severity index was identified the lowest range of genotypes 'Vilani', 'T36-2', 'T36-1' and highest 'S29-2' during four years period "(Fig. 2.)". The flax genotypes were identified as more susceptible to powdery mildew in the dries years. The all genotypes were showed quite low susceptible to powdery mildew with DSI range from 2.50 to $7.92 \%$ and statistically not significant between genotypes.

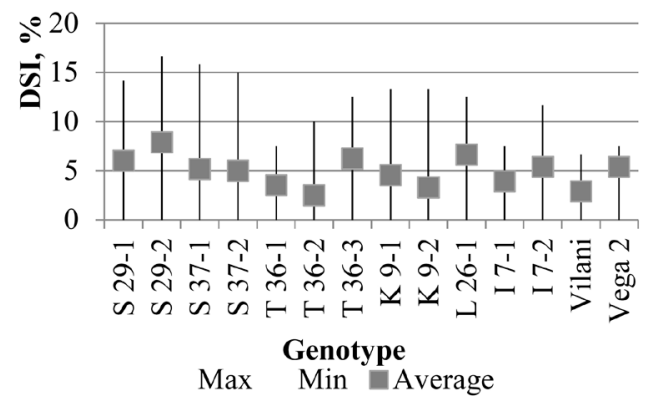

Fig. 2. Powdery mildew severity index during early yellow ripening stage of flax genotypes from 2015 to $2018\left(\mathrm{LSD}_{0.05}=8.61\right)$

Anthracnose severity index of flax was identified the lowest range of genotypes 'Vilani', 'Vega 2', 'T36-2' and highest 'I7-2' during 4 year period "(Fig. 3.)". The flax genotypes were showed more susceptible to anthracnose in the humidity years. All genotypes were observed quit low susceptible to anthracnose with average DSI range 
from 1.04 to $11.25 \%$ and statistically not significant between genotypes.

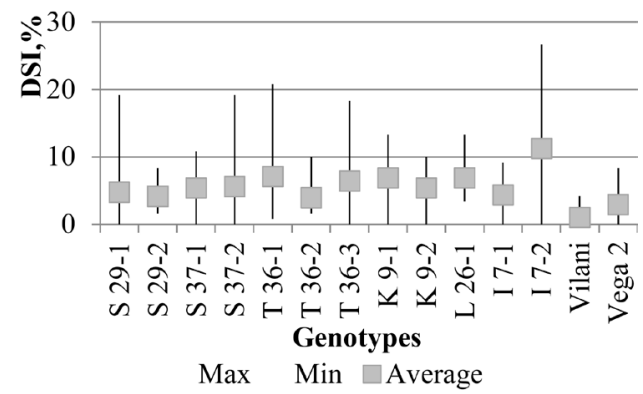

Fig. 3. Anthracnose severity index during early yellow ripening stage of flax genotypes from 2015 to $2018\left(\mathrm{LSD}_{0.05}=10.30\right)$

Pasmo occurrence on the flax was identified more in the high humid conditions. The pasmo severity index lowest range of genotypes 'T36-1', 'T36-2', 'Vilani' and statistically significant $(\mathrm{p} \leq 0.05)$ highest genotypes ' $\mathrm{S} 29$ 1', 'S29-2' was identified “(Fig. 4.)”. The DSI average ranged from 1.46 to $13.13 \%$.

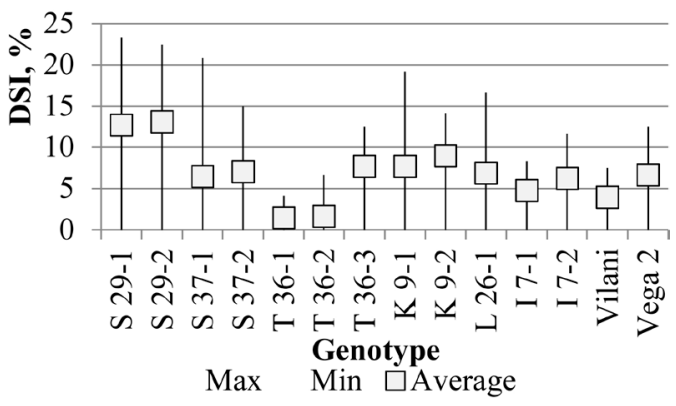

Fig. 4. Pasmo severity index during early yellow ripening stage of flax genotypes from 2015 to $2018\left(\mathrm{LSD}_{0.05}=9.60\right)$

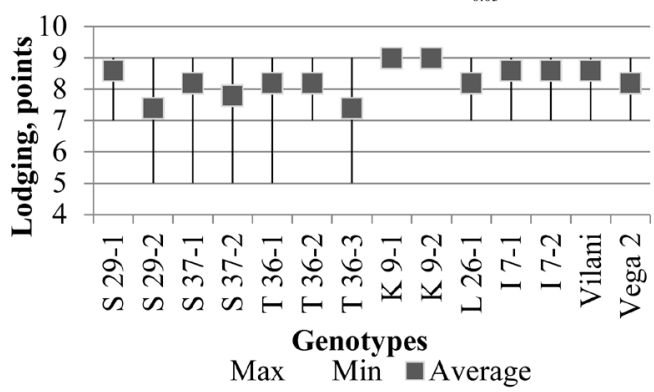

Fig. 5. Lodging during early yellow ripening stage of flax genotypes from 2014 to 2018

The resistance of flax to lodging between genotypes is variable from 2014 to 2018 “(Fig. 5.)". Highest resistance was identified of genotypes 'K9-1' and 'K9-2' as well lowest 'S29-2' and 'T36-3' and its reached up to 5 points in the certain years at the highest humidity conditions.

Summary was identified most perspective genotype of 'Vilani' with quit low susceptibility to anthracnose $(1.04 \%)$, pasmo $(3.96 \%)$ and powdery mildew $(2.92 \%)$ and resistance (9) to lodging.

\section{Conclusions}

The flax accessions 'Vilani', 'L26-1', 'K9-1', 'T361 ', 'S37-1' exhibited significant highest stem yield and technical height comparing to standard variety 'Vega 2' and are most valuable and perspective genotypes for flax breeding.
The information on the correlation of yield with related traits is the prerequisite to forming an effective plant breeding strategy aimed at its improvement. Genotypic and phenotypic correlations between yield and yield components were identified that total plant height, technical height and days to early yellow ripening stage played a major role on stem yield as well vessels per plant and harvest index on seed yield for fibre flax genotypes under Latvian condition.

Between all fax genotype were obtained most promising genotype 'Vilani' with complex highest resistance to fungal diseases and good lodging resistance.

\section{ACKNOWLEDGEMENTS}

This project "Evaluation of flax and hemp breeding material for integrated farming systems implementation" was financially supported by the Latvian Ministry of Agriculture.

\section{REFERENCE}

[1] M. M. M. Hussein, M. A. Abd El-Dayem and M. M. El-Refaie, "Effect of plant density and potassium fertilizer on yield and its quality of some flax genotypes under sandy soil condition," J. Agric. Sci., Mansoura Univ., vol. 32, pp. 99-115, 2007.

[2] A. B. Barky, O. M. Ibrahim, T. A. Elewa and M. F. El-Karamany, "Performance Assessment of Some Flax (Linum usitatissimum L.) Varieties Using Cluster Analysis under Sandy Soil Conditions," Agricultural Sciences, vol. 5, pp. 677-686, 2014.

[3] E. Rashwan, A. Mousa, A. EL-Sabagh and C. Barutçular, "Yield and Quality Traits of Some Flax Cultivars as Influenced by Different Irrigation Intervals," Journal of Agricultural Science, vol.8 (10), pp. 226 - 240, 2016.

[4] X. D. Xie, Z. Dai, Z. Yang, Q. Tang, J. Sun, X. Yang, X. Song, Y. $\mathrm{Lu}, \mathrm{D}$. Zhao, L. Zhang and J. Su, "Genomic variations and association study of agronomic traits in flax," BMC Genomics, vol. 19, pp. $512,2018$.

[5] Y. F. Wang, Z. Jankauskiene, C. S. Qiu, E. Gruzdeviene, S. H. Long, E. Alexopoulou, Y. Guo, J. Szopa, D. M. Hao, A. L. Fernando and H. Wang, "Fiber flax breeding in China and Europe," Journal of Natural Fibers, vol. 15(3), pp. 309-324, 2018.

[6] X. Li, W. Yan, H. Agrama, L. Jia, X. Shen, A. Jackson, K. Moldenhauer, K. Yeater, A. McClung and D. Wu, "Mapping QTLs for improving grain yield using the USDA rice mini-core collection," Planta, vol. 234, pp. 347-361, 2011.

[7] P. Ranjana, P. Satish and S. Devender, "Correlation and Path Coefficient Analysis for Improvement of Seed Yield in Linseed (Linum usitatissimum L.), “ Int. J. Curr. Microbiol. App. Sci., vol. 7(3), pp. 1853-1860, 2018.

[8] Y.F. Huang, D. Madur, V. Combes, C. L. Ky, D. Coubriche, P. Jamin, S. Jouanne, F. Dumas, E. Bouty, P. Bertin, A. Charcosset and L. Moreau, "The genetic architecture of grain yield and related traits in Zea maize L. revealed by comparing intermated and conventional populations," Genetics, vol. 186, pp. 395-404, 2010.

[9] S. D. Duguid, Flax. In: Vollmann J, Rajcan I, eds. Oil Crops, Handbook of Plant Breeding 4. Springer, New York, pp. 233-255, 2009. [E-book].

[10] A. Siddiqui, S. Shukla, A. Rastogi, A. Bhargava, A. Niranjan and A. Lehri, "Relationship among phenotypic and quality traits in indigenous and exotic accessions of linseed" Pesq. agropec. bras., Brasília, vol. 51 (12), pp. 1964-1972, 2016.

[11] M. S. Pujar, "Variability analysis of linseed (Linum usitatissimum L.) germplasm for yield and yield related components." M. S. thesis, Dharwad University of Agricultural Sciences, Dharwad, 2012.

[12] R. R. Kanwar, R. R.Saxena and R. E. Ekka, "Correlation and path co-efficient analysis of some quantitative traits in linseed (Linum usitatissimum L.)," International J. Plant Sciences (Muzaffarnagar), vol. 8 (2), pp. 395-397, 2013.

[13] E. M. Hussein, M. T. M. Mansour, M. E. M. Hassan, E. A. Elkady and K. K. Kasem, "Use of serology, SDS-PAGE, and RAPD analysis to evaluate resistance of flax to powdery mildew Egypt," J. Agric. Res., vol. 89 (1), 2011. 
[14] N. I. Loshakova, L. P. Kudravceva, L. N. Pavlova and T. A. Pohzmina, The role of collection of phytopathogenic casual agents - pathogens of flax diseases in the flax breeding programms for complex resistance to diseases. [Н. И. Лошакова, Л. П. Кудрявцева, Л. Н. Павлова, Т. А. Рожмина, Роль «коллекции фитопато- генных микроорганизмов - возбудителей болезней льна» в селекции льна на групповую устойчивость к болезням]. Oil crop. Scientific and technical newsletter. Russian Scientific Research Institute of oil crop [Масличные культуры. Научно-технический бюллетень. Всероссийского научноисследовательского института масличных культур], vol. 2, pp. 159-160, 2014, (in Russian).

[15] K. Y. Rashid, M. Desjardins, S. Duguid and D. A. Kaminski, "Diseases of flax in Manitoba and Saskatchewan in 2002," Canadian plant disease survey: Disease highlights edition, vol. 83, pp. 117-118, 2003.

[16] WRB. "World reference database for soil resources," World soil resources report No. 106, FAO, Rome, pp. 192, 2014

[17] J. Nozkova, M. Pavelek, M. Bjelková, N. Brutch, E. Tejklová, E. Porokhovinova and J. Brindz, "Descriptor List for Flax (Linums usitatissimum L.)," Slovak University of Agriculture in Nitra. pp. $102-106,2016$.

[18] N. I. Loshakova, T. V. Krilova and L. P. Kudravceva, Methodes for the phytopathological resistance evaluation to diseases of flax $[\mathrm{H}$. И. Лошакова, Т. В., Крылова, Л. П. Кудрявцева Методические указания по фитопатологической оценке устойчивости льнадолгунца к болезням). Moscow, 52. pp. 2000, (in Russian).

[19] U. Damm, R. J. O’Connell, J. Z. Groenewald and P. W. Crous, "The Colletotrichum destructivum species complex - hemibiotrophic pathogens of forage and field crops," Studies in Mycology, vol. 79(49), pp. 84, 2014

[20] G. L. Selyaninov, "About the agricultural evaluation of the climate, " Trudy, vol. 20, pp. 177-185, 1928.

[21] B. Skowera, E. Jędrszczyk, J. Kopcińska, A. M. Ambroszczyk and A. Kołton, "The effects of hydrothermal conditions during vegetation period on fruit quality of processing tomatoes," Polish Journal of Environmental Studies, vol. 23(1), pp. 195-202, 2014.

[22] H. A. Al-Jibouri, P. A. Millar and H. P. Robinson, "Genotypic and environmental variance and covariances in an upland cotton cross of interspecific origin, “Agron. J. vol. 50, pp. 633-637, 1958.

[23] D. R. Dewey and K. H. Lu, "A correlation and path coefficient analysis of components of crested wheat grass and seed production, “Agron. J. vol. 51, pp. 515- 518, 1959.

[24] A. Mikelsone, D. Grauda, V. Stramkale and I. Rashal, "Breeding for organic farming: obtaining and evaluation of flax somaclonal families" Environment. Technology. Resources Proceedings of the 8th International Scientific and Practical Conference, vol. 1, pp. 231-236, 2011.

[25] T. E. Nagaraja, K. R. Ajit and B. S. Golasangi, "Genetic variability, correlation and path analysis in linseed," J. Maharashtra Agric. Uni., vol. 34, pp. 282-285, 2009.

[26] K. M. V. Vardhan, S. S. Rao, "Genetic variability for seed yield and its components in linseed (Linum usitatissimum L.), "International Journal of Applied Biology and Pharmaceutical Technology, vol. 3, pp. 200-202, 2012.

[27] M. P. Reddy, B. N. Reddy, B. T. Arsul, and J. J. Maheshwari, "Genetic variability, heritability and genetic advance of growth and yield components of linseed (Linum usitatissimum L.), "International Journal of Current Microbiology and Applied Sciences, vol. 2, pp. 231-237, 2013.

[28] N.B. Brutch, "Correlation and factor analysis of some traits of flax,” Nauch.Tekhn. Byull. VIR, vol. 188, pp. 45-46, 1989.

[29] A.D. Stepin and M.I. Ponamareva, "Correlation of the Yield of Straw and Flax Fibers with Its Morphological Traits," Knowledge of Young Researchers to the Science of the New Century, pp. 37-39, 2001.

[30] L. Burako, "Genetic diversity study of linseed genotypes on acidic soil at bedi trial site, central highland of Ethiopia," M.S. Thesis, Dept. of Biology (Applied Genetics). Addis Ababa Univ, 2010.

[31] M. M. Rahimi, M. A. Zarei and A. Arminian, "Selection criteria of flax (Linum usitatissimum L.) for seed yield, yield components and biochemical compositions under various planting dates and nitrogen,” African J. Agric Res., vol. 6(13), pp. 3167-3175, 2011.

[32] A. M. Tariq, T. Hussain, I. Ahmad, M. Saghir, M. Batool, M. Safdar and M. Tariq, "Association analysis in Linseed (Linum usitatissimum L.), “ J. Biol. Agric. Healthc., vol. 4, pp. 62014.

[33] A. G. Sonwane, M. N. Kathale, M. K. Ghodke and A. U. Ingle, "Correlation and path analysis studies for yield and yield contributing characters in linseed (Linum usitatissimum), " Trends Biosciences, vol. 8 (14), pp. 3655 - 3659, 2015.

[34] D. Ibrar, R. Ahmad, M.Y. Mirza, T. Mahmood, M. A. Khan, and M. S. Iqbal, "Correlation and Path analysis for yield and yield components in Linseed (Linum usitatissimum L.), " J. Agric. Res., vol. 54, pp $153-159,2016$.

[35] K. Bačelis and E. Gruzdeviene,, "Resistance of fibre flax varieties to Colletotrichum lini Manns et Boley, "Biologija, vol. 3, pp. 4 -9, 2001. 